\title{
Effect of mimosa diplotricha leaf meal on the organ weights and organoleptic properties of three broiler strains
}

Ezeakacha, E. M., Okonkwo, J. C. and Ezenyilimba, B.

${ }^{\prime}$ Department of Animal Science and Technology, Faculty of Agriculture, Nnamdi Azikiwe

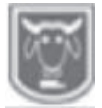

University Awka

Corresponding author:drjcokonkwo@gmail.com or gist4ela@gmail.com Phone:0803544358

\begin{abstract}
The effect of Mimosa diptotricha teaf meat (MDLM) on the organ weights and organoteptic properties of three broiler breeds was studied using 120 day-old chicks reared for eight weeks. The work was carried out using randomized complete block design. The breeds namely Arbo Acre, Cobbs and Ross were designated as treatment 1, 2 and 3, respectively with three replicates each. Two diet groups; diet with $2 \%$ Mimosa diplotrich leaf meal and diets without the leaf meal were administered. The organ weights and organoleptic properties of the broiler strains were determined. Mimosa diplotricha had no significant effect on the heart, spleen, gizzard and liver weights of the birds. Furthermore, similar spleen weights were obtained across the breeds, while discrepancies were observed in heart, gizzard and liver weights of the breeds. Cobbs best tolerated the leaf meal with respect to organ weights and gave the best taste, flavor intensity and desirability. Results showed that Mimosa diplotrich a could be used as a partial replacement of wheat offal in broiler diets. However, lesser concentration may be used for Ross breed. Regardless of feed inclusion, Cobbs is observed as the best breed in comparison to Arbo acre and Ross broilers with respect to organoleptic properties and organ weights.
\end{abstract}

Keywords: breeds, Mimosa, organ weights, organoleptic

\section{Introduction}

The poultry industry has long been at the mercy of poultry feed manufacturers. Many livestock farmers have opted out of the industry following the unbearable prices of feeds, yet, many more have plunged in with enough capital to handle production from start to finish, managing the little profit they can gather. Most production cost estimates range from $60 \%$ to $70 \%$ as being feed costs (Behnke and Beyer, 1994) but more recent is its increase to over $70 \%$ as pointed out by Matthew and Moji (2008). High cost of feed is largely dependent on the availability of feed ingredients which in turn affects the quality of feeds as feed manufacturers do not meet up with certain necessary inputs. Not to be forgotten is the rapid growth of human and livestock population which while creating an increased food and feed requirement in the less developed countries, demand that alternative feed resources be identified and evaluated as stated by Odunsi (2003). The reason behind feed cost rising is the type and concentration of protein supplementation with poultry diets (Nworgu, 2015). Okah and Onwujiariri (2012) reported that any efforts towards reducing the cost of protein sources will decrease the poultry production cost and livestock cost in general. These efforts should not only aim at reduction of protein costs but provision of high quality protein. Quality protein determines the efficiency of feed utilization.

As D'Souza (2007) states, the poultry industry will have to look to history for the feed solutions of the future. A promising alternative to conventional protein sources is the leaf meal of some legumes and 
browse plants (Esonu et al., 2003). Ravindran (1992) noted that leaf meals provide not only proteins but vitamins and minerals.

The suitability and efficiency of these leaf meals is monitored by changes in organ characteristics like organ weights and organoleptic properties of test animals. Such changes in organ characteristics could be favourable or detrimental to the animals, thereby determining whether or not the leaf meal is suitable. Organoleptic properties are the traits which determine the regular purchase and consumption of meat by consumers (Amao et al., 2015); meat with little or no attraction to consumers is most likely to be bullied out of the market. Breed plays an important role in the nutrient quality requirement of a diet and remains one of the major factors that affect the consumption and utilization of feedstuff. Specificity of each breed tells how well the bird utilizes feed and is able to meet consumer standards.

A largely available leguminous plant having great potential is the Mimosa diplotricha, formerly known as Mimosa invisa (Anon, 2001). Mimosa diplotricha is a biennial or perennial legume (Holm et al., 1977) which starts as an erect plant and grows into a spiny climbing shrub with the capacity to smother competing plants in its domain (Alabi et al., 2001). It belongs to the genus Mimosa, in the legume family Fabaceae or Mimosaceae. Laboratory analyses have shown that the protein concentration of Mimosa diplotricha leaf meal is 23.34\% (Nworgu and Egbunike, 2013). Mimosa diplotricha leaf meal is a potential source of protein in broiler diet which has majorly been untapped and could help overcome cost challenge due to its cheap availability and impressive protein percentage.

Chinelo et al. (2016) studied the nutritive value of the different morphological components of Mimosa diplotricha. She found its leaves to contain a higher concentration of carbohydrates, ash and fat in relation to its stem and root. Mimosa diplotricha has also been compared with its sister specie, Mimosa pudica and found to be of higher protein content. There is dearth of research report on its use as a feed ingredient in the broiler production. Consequently, the study was designed to ascertain the effect of Mimosa diplotricha leaf meal on the organ weights and organoleptic properties of three major broiler strains in Nigeria.

\section{Materials and methods Experimental site}

The research was undertaken at the poultry house of the Department of Animal Science and Technology, Nnamdi Azikiwe University, Awka, Anambra State, Nigeria. Awka is the Capital of Anambra State and it is in the tropical rainfall zone of Nigeria. The mean annual temperature, rainfall and humidity are $27.0^{\circ} \mathrm{C}, 1828$ and $80 \%$ respectively. The driest month is December with a rainfall of $7 \mathrm{~mm}$ and the highest is September having an average of $306 \mathrm{~mm}$. Rainy season lasts for six months, occurring from April to July and September and October. It is located within the latitude, $6^{\circ} 12^{\prime} 25^{\prime \prime} \mathrm{N}$ and longitude, $7^{0}$ 04'04'E.

\section{Sources and processing of Mimosa diplotricha leaf meal}

Mimosa diplotricha leaves were harvested green around the Faculty of Agriculture, Nnamdi Azikiwe University, Awka within the months of January, February and March. They were harvested by plucking manually the stems of the plant consisting of its leaves and spreading for 3 days to dry. The dried, crispy, green leaves were then dusted out of the stems and sieved to ensure 
proper removal of its stems. Given the small sizes of the leaves, grinding was not done. They were packaged in air-tight sacs for subsequent use.

\section{Feeding trial}

\section{Experimental diets}

The feeding trial was carried out in two phases: the starter phase and the finisher phase. Two starter diets were formulated; diet 1 with no mimosa inclusion as the control diet and diet 2 with 2\% MDLM, in partial replacement of wheat offal. The finisher diet was adjusted to suit the required broiler finisher phase of lesser protein and higher carbohydrates. The ingredient compositions of both diets are shown in Tables 1 and 2, respectively.

Table 1: Composition of the starter diet

\begin{tabular}{lll}
\hline Ingredients & \multicolumn{2}{l}{ Mimosa diplotricha Inclusion } \\
\cline { 2 - 3 } & $0 \%$ & $2 \%$ \\
\hline Maize & 50.00 & 50.00 \\
Soybean Meal & 30.00 & 30.00 \\
Mimosa diplotricha leaf meal & 0.00 & 2.00 \\
Wheat Offal & 8.00 & 6.00 \\
Fish meal & 2.00 & 2.00 \\
Blood meal & 2.00 & 2.00 \\
Palm kernel cake & 4.00 & 4.00 \\
Bone meal & 3.00 & 3.00 \\
Salt & 0.25 & 0.25 \\
Lysine & 0.25 & 0.25 \\
Methionine & 0.25 & 0.25 \\
*Mineral/vitamin premix & 0.25 & 0.25 \\
Calculated analysis & & \\
Crude protein $(\%)$ & 22.46 & 22.48 \\
\hline
\end{tabular}

*to provide Vit A; 10,000,00iu, Vit D3; 2,000,00iu,Vit E; 10,000iu, Vit K; 2500mg, Vit $\quad$ B1; 2000mg, Vit B2; 70,000mg, Vit B6; 2000mg, Niacin; 50,000mg, Vit B12; 15mg, Pantothenic; 5000mg, Folic Acid; 750mg, Choline Chloride; 400gr, BHT; 125gr, Manganese; 10grZinc; 100gr, Iron; 30gr, Copper; 10gr, Iodine; 1.5gr, Selenium; 200mgr, Cobalt; 20 0mgr, Lysine; 15gr, Methionine; 20gr, Biotin; 100mgr.

Table 2: Composition of the finisher diet

\begin{tabular}{lll}
\hline Ingredients & \multicolumn{2}{l}{ Mimosa diplotricha Inclusion } \\
\cline { 2 - 3 } & $0 \%$ & $2 \%$ \\
\hline Maize & 60.00 & 60.00 \\
Soybean meal & 20.00 & 20.00 \\
Mimosa diplotricha leaf meal & 0.00 & 2.00 \\
Wheat Offal & 8.00 & 6.00 \\
Fish meal & 2.00 & 2.00 \\
Blood meal & 2.00 & 2.00 \\
Palm kernel cake & 4.00 & 4.00 \\
Bone meal & 3.00 & 3.00 \\
Salt & 0.25 & 0.25 \\
Lysine & 0.25 & 0.25 \\
Methionine & 0.25 & 0.25 \\
*Mineral/vitamin premix & 0.25 & 0.25 \\
Calculated analysis & & \\
Crude protein (\%) & 18.95 & 18.97 \\
\hline *to provide Vit A; 10, 000,00iu, Vit D3; 2,000,00iu,Vit E; 10,000iu, Vit K; 2500mg, Vit B1; 2000mg, Vit B2; 70,000mg, Vit B6; 2000mg, \\
Niacin; 50,000mg, Vit B12; 15mg, Pantothenic; 5000mg, Folic Acid; 750mg, Choline Chloride; 400gr, BHT; 125gr, Manganese; 10grZinc; \\
100gr, Iron; 30gr, Copper; 10gr, Iodine; 1.5gr, Selenium; 200mgr, Cobalt; 200mgr, Lysine; 15gr, Methionine; 20gr, Biotin; 100mgr.
\end{tabular}


The proximate composition of Mimosa diplotricha leaf meal as given by Nworgu \&
Egbunike(2013) is shown in Table 3.

Table 3: Proximate analysis of Mimosa diplotricha leaf meal

\begin{tabular}{ll}
\hline Fraction (\%) & Mimosa diplotricha leaf meal \\
\hline Dry Matter & 89.99 \\
Crude Protein & 23.34 \\
Crude Fiber & 11.29 \\
Ether Extract & 2.38 \\
Ash & 4.25 \\
Nitrogen Free Extract (NFE) & 58.74 \\
\hline
\end{tabular}

Source: Nworgu and Egbunike (2013)

\section{Experimental birds}

One hundred and twenty day-old broiler chicks of the breeds were used to carry out this experiment. It was made of forty birds each for the Arbo Acre, Cobbs and Ross broiler breeds. They were purchased from Zartech Farms, Ibadan, Oyo State. The chicks were fed commercial broiler starter for two weeks. Brooding was done with the chicks in four groups of thirty and adequate heat provided. Light was set out at night for enhanced growth. At the end of two weeks, the birds were placed in three groups representing the three broiler breeds. Each group was separated in two with one half being fed on diet 1 and the other half on diet 2. The birds were fed their respective experimental diets once a day. Routine medications and antibiotics were administered.

By the end of the starter phase, the finisher experimental diet was given to the birds as in the starter phase.

\section{Data collection}

\section{Organ weights}

At the $8^{\text {th }}$ week, data were collected on organ weights of eighteen experimental birds. Three birds each were selected from the two diets in each breed. The birds were slaughtered according to the Modified Kosher method of poultry slaughter and allowed to bleed for 90 seconds to prevent discoloration of the cooked meat. The slaughtered birds were scalded in hot water for easy de-feathering and the visceral organs were extracted. The heart, liver, gizzard, lung and kidneys were taken out and placed in a previously washed bowl to avoid contamination and for subsequent weighing. These organs were weighed using a sensitive electronic scale.

\section{Organoleptic properties}

Samples were collected from the breast of the experimental birds and cut into $50 \mathrm{~g}$ sizes. They were cooked for 5 minutes with $5 \mathrm{~g}$ of salt and placed in small insulated coolers to maintain temperature. The coolers were in turn put in a bigger cooler for further temperature control. The samples were then served to 11 panelists comprising staff and students of Nnamdi Azikiwe University, Awka. The panelists assessed the juiciness, taste, texture, flavor intensity and desirability of each sample using a questionnaire (See Appendix I). The assessment was done using a 5-point Hedonic scale as described by BarylkoPikielna (1975) with 1 being the least favourable of each parameter and 6 being its best condition.

\section{Statistical analysis}

Data for organ weights were subjected to a two-way analysis of variance test using GENSTAT release 7.2 Statistical Software. The means were separated using the Least Significant Difference (LSD) Test. Data for organoleptic characteristics were subjected to a two-way analysis of variance test using 
SPSS version 22 Statistical Package. The means were separated using the Duncan New Multiple Range Test as outlined by Duncan (1955).

\section{Results}

Effects of Mimosa diplotricha inclusion on the organ weights of broilers

The effects of Mimosa diplotricha inclusion on the organ weights of broilers are presented in Table 4. Regardless of breed, inclusion of Mimosa diplotricha leaf meal had no significant effect $(\mathrm{p}>0.05)$ on the weights of the heart, spleen, gizzard and liver of broiler birds placed on such diet although this was not the case for the weight of the intestine. There was a significant $(\mathrm{p}<0.05)$ difference in the consumption of Mimosa diplotricha on the intestine weight of the birds with a value of 110.4 and 126.9 for $0 \%$ and $2 \%$ inclusion, respectively. Figure 1 is a bar chart comparing $0 \%$ and $2 \%$ MDLM inclusion levels on various organ weights of broilers.

Table 4: Effects of Mimosa diplotricha inclusion on the organ weights of broilers

\begin{tabular}{lccc}
\hline \multirow{2}{*}{ Organs } & \multicolumn{3}{c}{ Inclusion Levels } \\
\cline { 2 - 4 } & $\mathbf{0 \%}$ & $\mathbf{2 \%}$ & LSD $_{\mathbf{0 . 0 5}}$ \\
\hline Heart & $9.22 \pm 0.192$ & $8.78 \pm 0.192$ & Ns \\
Spleen & $1.67 \pm 0.157$ & $1.78 \pm 0.157$ & Ns \\
Gizzard & $48.70 \pm 1.856$ & $45.20 \pm 1.856$ & Ns \\
Liver & $37.00 \pm 1.558$ & $36.70 \pm 1.558$ & Ns \\
Full Intestine & $110.40 \pm 4.734$ & $126.90 \pm 4.734$ & 14.590 \\
\hline ns $=$ not significant & All values are in grams & &
\end{tabular}

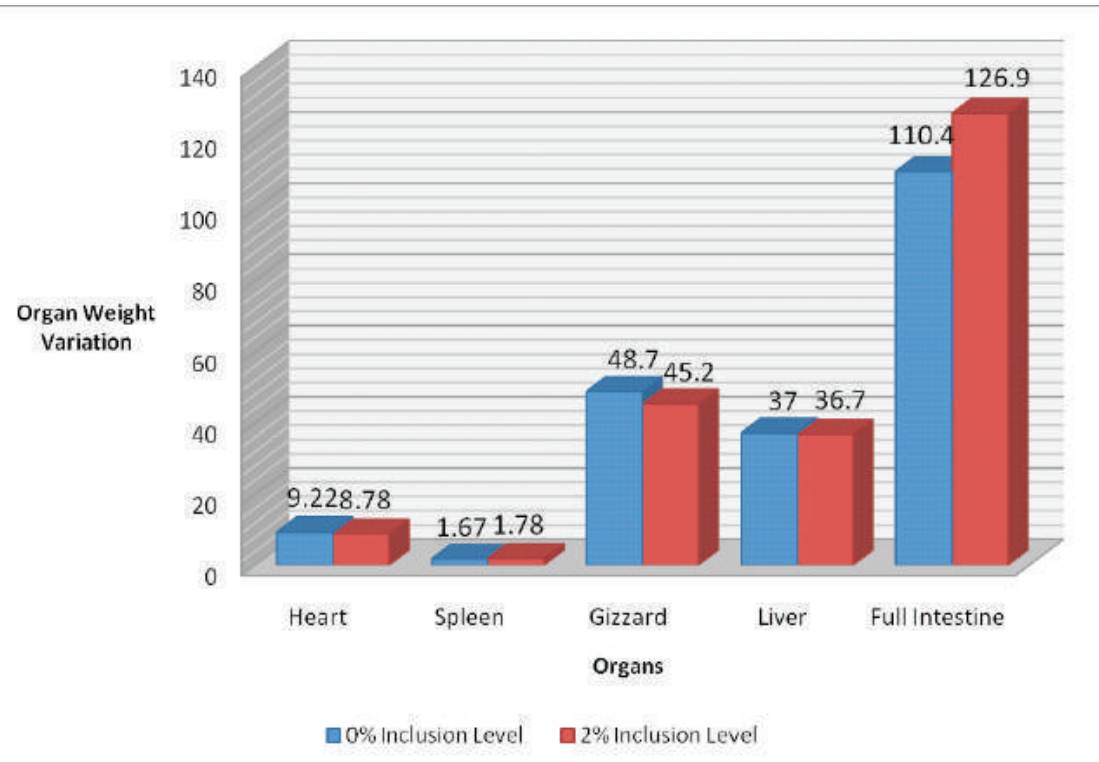

Figure 1: Effects of Mimosa inclusion levels on the organ weights of broilers

\section{Effects of breeds on the organ weights of broilers}

The effects of breeds on the organ weights of broilers are shown in Table 5 and Figure 2 showed the variation in bar chart. Arbo acre showed a significant $(\mathrm{p}<0.05)$ lower heart weight than Cobbs and Ross broilers. There were no significant differences $(p>0.05)$ on the spleen weights of all the experimental breeds. Significant difference was observed in the gizzard weights of Cobbs and Ross breeds and Arbo acre and 
Ross breeds, whereas non-significant variations were observed in the gizzard weights of Arbo acre and Cobbs breeds.
Ross broiler was seen to be significantly higher in the gizzard weight.

Similar occurrence is seen in the weights of the liver and intestine.

Table 5: Effects of breeds on the organ weights of broilers

\begin{tabular}{lcccc}
\hline \multirow{2}{*}{ Organs } & \multicolumn{4}{c}{ Breeds } \\
\cline { 2 - 5 } & Arbo acre & Cobbs & Ross & LSD $_{\mathbf{0 . 0 5}}$ \\
\hline Heart & $8.33 \pm 0.236$ & $9.33 \pm 0.236$ & $9.33 \pm 0.236$ & 0.726 \\
Spleen & $1.67 \pm 0.192$ & $1.83 \pm 0.192$ & $1.67 \pm 0.192$ & Ns \\
Gizzard & $41.30 \pm 2.273$ & $43.30 \pm 2.273$ & $56.20 \pm 2.273$ & 7.000 \\
Liver & $33.00 \pm 1.908$ & $35.00 \pm 1.908$ & $42.50 \pm 1.908$ & 5.880 \\
Intestine & $112.70 \pm 5.798$ & $102.30 \pm 5.798$ & $141.00 \pm 5.798$ & 17.860 \\
\hline
\end{tabular}

ns =no significant difference

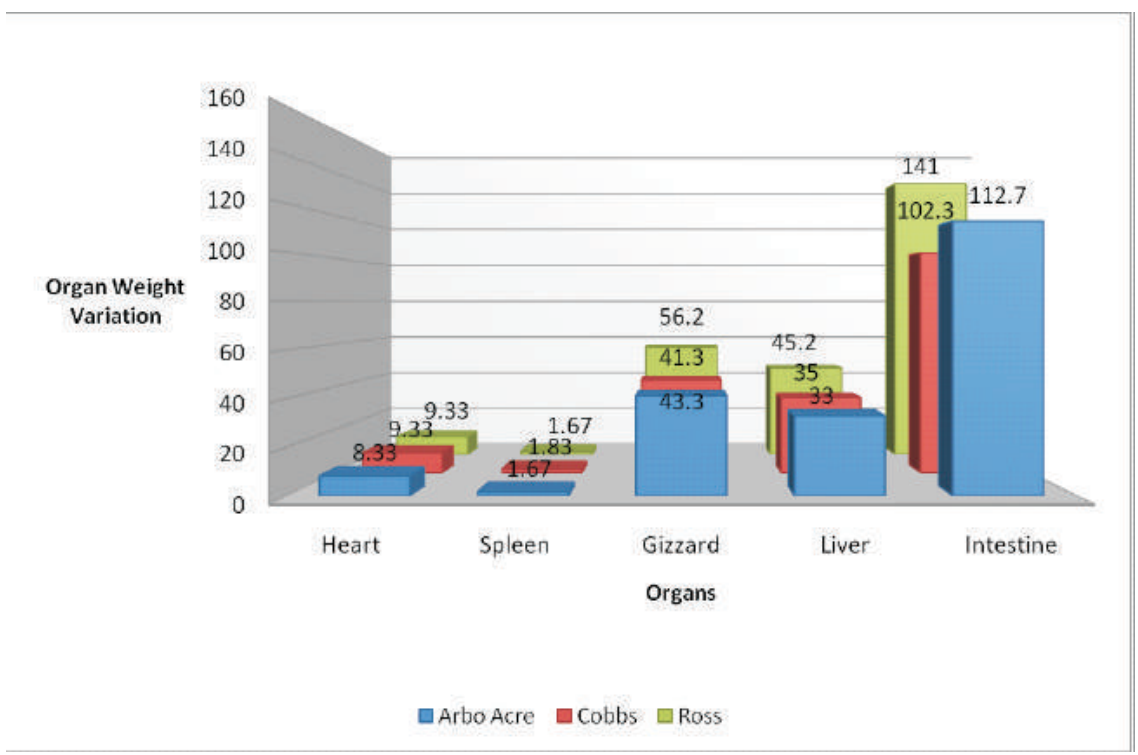

Figure 2: Effects of breeds on the organ weights of broilers

\section{Interaction of breeds and feed inclusion} on the organ weights of broilers

The interaction between breeds and MDLM inclusion on the organ weights of broilers are presented in Table 6 and represented in a sketch in Figure 3. Mimosa diplotricha leaf meal administered to Cobbs and Ross breeds significantly affected the heart weight of the breeds but had non-significant effect on the heart weight of Arbo acre broiler breed.
There was non-significant interaction observed between feed inclusion and breeds with respect to the spleen weight. The gizzard and liver weights were affected by all the breeds' consumption of Mimosa diplotricha leaf meal. Ross broiler breed had a significant effect with respect to weight of intestine when fed the leaf meal as against Arbo acre and Cobbs broilers which were not affected by Mimosa consumption. 
Ezeakacha, Okonkwo and Ezenyilimba.

Table 6: Interaction of breeds and inclusion on the organ weights of broilers

\begin{tabular}{ccccccc}
\hline \multirow{2}{*}{ Breeds } & $\begin{array}{c}\text { Feed } \\
\text { Inclusion } \\
(\%)\end{array}$ & \multicolumn{5}{c}{ Organs } \\
\cline { 3 - 7 } & & Heart & Spleen & Gizzard & Liver & Full Intestine \\
\cline { 3 - 7 } & & $8.00 \pm 0.333$ & $1.67 \pm 0.272$ & $45.00 \pm 3.215$ & $36.00 \pm 2.698$ & $113.70 \pm 8.199$ \\
Arbo acre & 0 & $8.67 \pm 0.333$ & $1.67 \pm 0.272$ & $37.70 \pm 3.215$ & $30.00 \pm 2.698$ & $111.70 \pm 8.199$ \\
& 2 & $11.00 \pm 0.333$ & $2.00 \pm 0.272$ & $42.00 \pm 3.215$ & $34.00 \pm 2.698$ & $103.70 \pm 8.199$ \\
Cobbs & 0 & $7.67 \pm 0.333$ & $1.67 \pm 0.272$ & $44.70 \pm 3.215$ & $36.00 \pm 2.698$ & $101.00 \pm 8.199$ \\
& 2 & & & & \\
Ross & 0 & $10.67 \pm 0.333$ & $1.33 \pm 0.272$ & $59.00 \pm 3.215$ & $41.00 \pm 2.698$ & $114.00 \pm 8.199$ \\
& 2 & $10.00 \pm 0.333$ & $2.00 \pm 0.272$ & $53.30 \pm 3.215$ & $44.00 \pm 2.698$ & $168.00 \pm 8.199$ \\
& LSD $_{0.05}$ & 1.027 & Ns & 9.910 & 8.310 & 25.260 \\
\hline
\end{tabular}

ns $=$ not significant

All values are in grams

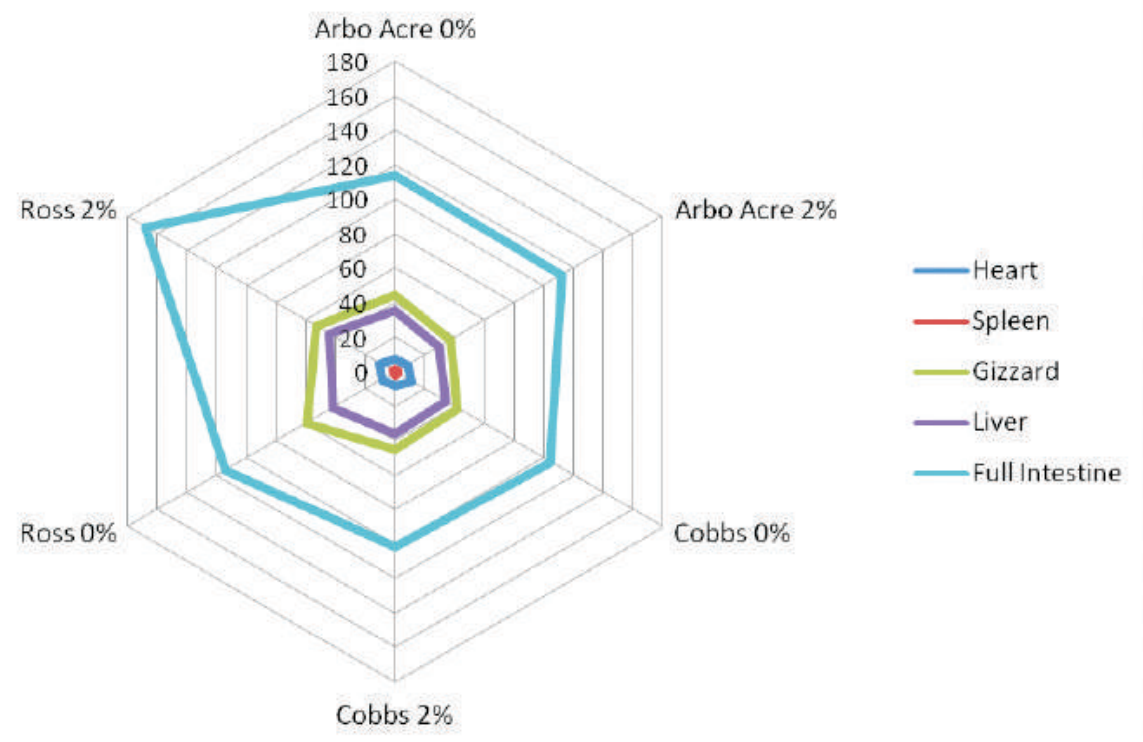

Figure 3: Interaction of breeds and MDLM inclusion on the organ weights of Broilers

Effects of MDLM inclusion and breed on the organoleptic properties of broilers

The effects of Mimosa diplotricha leaf meal (MDLM) inclusion on the organoleptic properties of three broiler breeds are given in Table 7 and in bar chart 4. Juiciness and Tenderness are seen to be significantly not affected by the inclusion of MDLM and breed of the broilers. Arbo acre fed 2\% MDLM is observed to be significantly different from its $0 \%$ inclusion and from Cobbs and Ross. Flavour Intensity and Desirability are similar for all breeds and inclusions. 
Effect of Mimosa diplotricha leaf meal on the organ weights and organoleptic properties of three broiler strains

Table 7: Effects of Mimosa diplotricha inclusion and breeds on the organoleptic properties of broilers

\begin{tabular}{lllllll}
\hline & \multicolumn{5}{c}{ Breeds/Inclusion levels } \\
\cline { 2 - 7 } & Arbo acre & \multicolumn{4}{c}{ Cobbs } & Ross \\
\hline Parameters & $\mathbf{0 \%}$ & $\mathbf{2 \%}$ & $\mathbf{0 \%}$ & $\mathbf{2 \%}$ & $\mathbf{0 \%}$ & $\mathbf{2 \%}$ \\
\hline Juiciness & $4.27 \pm 0.09^{\mathrm{a}}$ & $3.86 \pm 0.59^{\mathrm{a}}$ & $4.09 \pm 0.36^{\mathrm{a}}$ & $4.09 \pm 0.27^{\mathrm{a}}$ & $4.05 \pm 0.05^{\mathrm{a}}$ & $3.41 \pm 0.23^{\mathrm{a}}$ \\
Tenderness & $3.64 \pm 0.36^{\mathrm{a}}$ & $4.32 \pm 0.05^{\mathrm{a}}$ & $3.68 \pm 0.68^{\mathrm{a}}$ & $3.45 \pm 0.09^{\mathrm{a}}$ & $3.59 \pm 0.14^{\mathrm{a}}$ & $3.18 \pm 0.36^{\mathrm{a}}$ \\
Taste & $4.22 \pm 0.14^{\mathrm{ab}}$ & $3.77 \pm 0.23^{\mathrm{a}}$ & $4.32 \pm 0.14^{\mathrm{b}}$ & $4.41 \pm 0.05^{\mathrm{b}}$ & $3.95 \pm 0.05^{\mathrm{ab}}$ & $3.95 \pm 0.05^{\mathrm{ab}}$ \\
Flavour & $3.50 \pm 0.14^{\mathrm{a}}$ & $3.41 \pm 0.59^{\mathrm{a}}$ & $3.55 \pm 0.18^{\mathrm{a}}$ & $3.68 \pm 0.14^{\mathrm{a}}$ & $3.09 \pm 0.00^{\mathrm{a}}$ & $3.14 \pm 0.05^{\mathrm{a}}$ \\
Intensity & & & & & & \\
Desirability & $3.86 \pm 0.05^{\mathrm{a}}$ & $3.64 \pm 0.55^{\mathrm{a}}$ & $3.77 \pm 0.14^{\mathrm{a}}$ & $3.91 \pm 0.09^{\mathrm{a}}$ & $3.32 \pm 0.41^{\mathrm{a}}$ & $3.18 \pm 0.09^{\mathrm{a}}$ \\
\hline
\end{tabular}

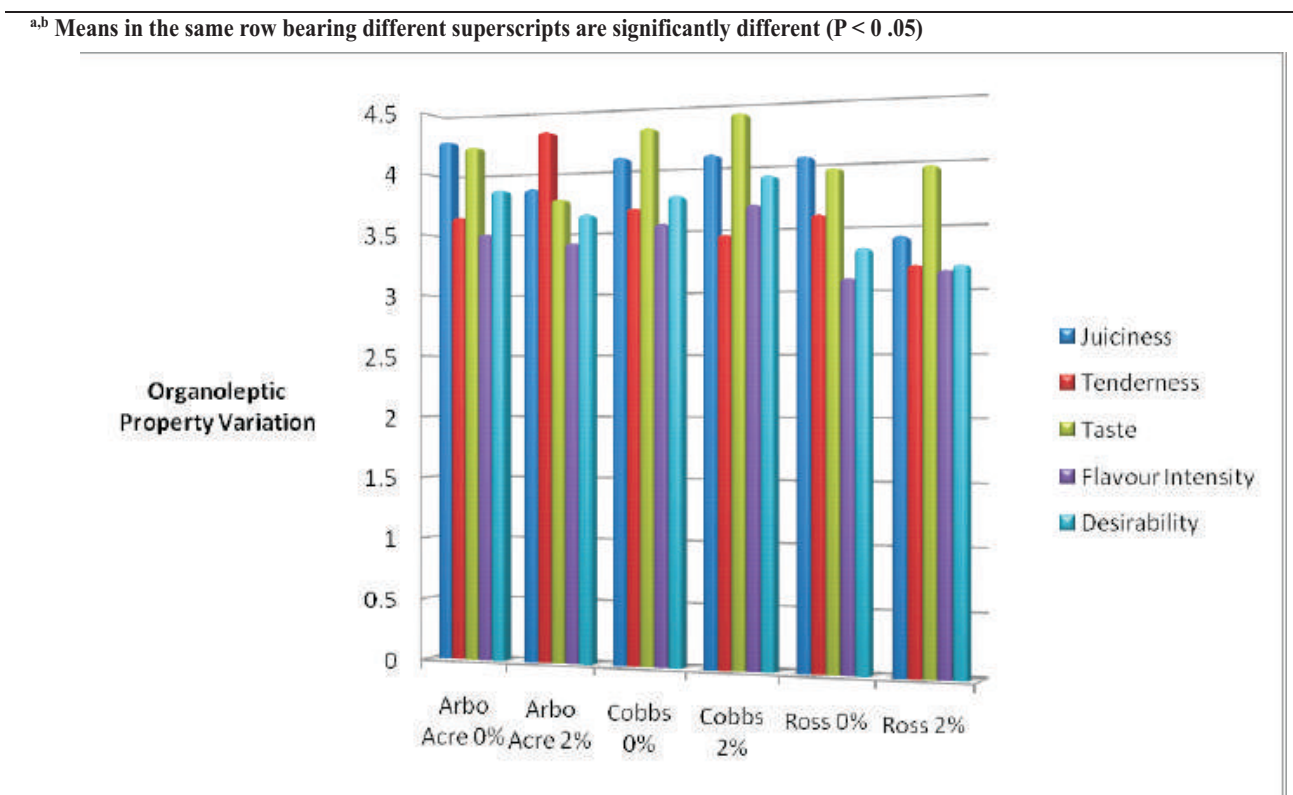

Figure 4: Effects of Mimosa diplotricha inclusion and breeds on the organoleptic properties of broilers

\section{Discussion}

\section{Effects of Mimosa diplotricha inclusion and breeds on the organ weights of broilers}

On the similarity in the weights of the heart, spleen, empty gizzard and liver, Table 4 showed that the inclusion of Mimosa diplotricha had no effect on these organs, irrespective of the breed. Olowu et al. (2013) and Ayo-Ajasa et al. (2016) reported a similar result while working with Neem leaf meal and Moringa oleifera leaf meal respectively. This study also supports González-Alvarado et al. (2007); Martinez et al. (2015) who observed no differences on spleen weight in broilers on high-fibre diets. The result of this study is at variance with Agbabiaka et al. (2012) who claimed that consumption of high fibre diet causes an increase in gizzard weight. This shows that the fibre content is not too high as to cause an increase in the gizzard weight.

The increased weight of the full intestine upon consumption of MDLM could be attributed to slower digestibility leading to increased retention of the digesta in the intestine. This is in line with Meremikwu et al. (2013), Svihus (2011) and Diarra et al. 
(2014) who noted that consumption of high fibre diets resulted in increased digesta retention. Cross (2004) also reported that broilers fed diets containing mimosa showed decreased digestibility of amino acids. She attributed this to the presence of one or more phenolic compounds.

Reduced digestibility decreases feed intake which in turn leads to overall poor performance of the birds. The insignificant decrease in organ weights in this study shows the tendency of Mimosa inclusion to reduce broiler performance as these weights are determined by the weight of the birds (Tuleun and Igba, 2007).

Significant effect of breeds on the heart, gizzard and liver weights irrespective of diet, correlates with Taha et al. (2010) who in their study with Shaver A, B, C, Salam and Mandarah broiler strains, reported a significant effect of breed on these weights. Fernandes et al. (2013) reported a significant difference between Cobb 500 Slow, Cobb Fast, Ross 308, Ross 508, Hybro Plus and Avian 48 broilers. In the present study, Arbo acre was observed to have a significantly lower heart weight and Ross, significantly higher gizzard and liver weights. It does not agree with Olawumi and Fagbuaro (2011) as they noted no significant effect of breed on gizzard and liver weights with Arbo acre (43.8 and 39.6 respectively), Hubbard and Marshall broiler breeds. It also opposes Dariusz et al. (2013) whose study on Ross 308, Hubbard Flex and Hubbard F15 observed no significant effect of breeds on these weights with the liver, heart, gizzard and spleen weights of Ross broiler as 43.6, 9.6, 24.7 and 2.7 respectively. Ross is observed to have a higher liver weight than Cobbs and Arbo acre but this does not conform to Kow et al. (2015) and Andrea et al. (2005) as they report Cobbs as having a higher liver weight (85) than Ross (70).
Johnson and McNab (1983) reported that muscular activity of the gizzard in grinding feed particles determines its size. Ross broiler has the highest gizzard weight and is hence, capable of more efficient feed grinding than Arbo Acre and Cobbs. The liver which was also significantly higher in this breed is more efficient in its action of detoxification in comparison with other breeds in the present study. Cobbs was observed to have the highest spleen weight, giving an adept immune function than Arbo Acre and Ross as the spleen is known to be a part of the immune system. Ross is shown to have higher intestine weight than Cobbs and Arbo acre broilers.

Significant interaction of Breed and Feed Inclusion affected the weights of the heart, gizzard, liver and full intestine of the birds, corresponding with Olawumi and Fagbuaro (2011) who gave same results in his study with Arbo acre, Hubbard and Marshall broilers.

An increased liver weight of Cobbs and Ross broilers may be attributed to residual toxicity of the Mimosa diplotricha leaf meal included. Sun-drying of the leaves may not have eliminated the toxicity of the plant completely. Ross particularly showed a significant increase in heart weight. The heart supports the liver in detoxification and this together with the higher liver weight, revealed the unacceptability of the leaf meal with the breed. The heart weight of Arbo acre was not affected by this breed's consumption of the leaf meal.

A decrease was rather seen in the liver, gizzard and intestine weights of Arbo acre. This decrease showed the poor performance of this breed as a result of Mimosa diplotricha inclusion. The spleen weight of all breeds was not affected by the leaf meal consumed, thereby implying that the quantity of Mimosa diplotricha leaf meal included was too small to have an 
effect on the immune system of the broilers. Ross broiler showed significant increase in its full intestine weight with Mimosa inclusion. This signifies longer retention of digesta in this breed.

\section{Effects of Mimosa diplotricha inclusion and breeds on the organoleptic properties of broilers}

Ross was observed to be the toughest in diets with no Mimosa inclusion and $2 \%$ inclusion, respectively although all breeds are significantly similar in tenderness. This concurs with Abdullah et al. (2010) who studied the Lohman, Hubbard JV, Hubbard classic and Ross breeds and reported Ross as a tough broiler breed. This breed is also observed to be the poorest with respect to juiciness, flavor intensity and desirability.

Consumption of Mimosa diplotricha reduced the juiciness of Arbo acre and Ross broilers but had no effect on that of Cobbs broilers. It also resulted in a decrease in tenderness in Cobbs and Ross broilers although this was but a slight decrease in Cobbs. Arbo acre fed the leaf meal had the poorest taste but an improvement in taste was observed in Cobbs fed Mimosa diplotricha. Regardless of the feed consumed, Cobbs was observed to be most preferred with respect to tenderness, taste and flavor Intensity. Cobbs broiler upon consumption of Mimosa diplotricha leaf meal, remained most preferred in terms of taste, flavor intensity and in addition, juiciness and desirability.

\section{Conclusion}

The use of 2\% Mimosa diplotricha leaf meal is suitable in broiler diets given that it had no apparent effect on the weight of organs of broilers in this study. Cobbs was observed to be more tender and have better taste than other breeds with and without the leaf meal inclusion. From a commercial standpoint, this inclusion enables feed cost reduction and higher consumer preference

\section{References}

Abdullah Abdullah, Y., Nafez AlBeitawi, Murad Rjoup, M.S. and Majdi Abu Ishmais. 2010. Growth Performance, Carcass and Meat Quality Characteristics of Different Commercial Crosses of Broiler Strains of Chicken. Journal of Poultry Science. 47: 13-21

Agbabiaka, L. A., Madubuike, F. N., Esonu, B. O. 2012. Performance, Carcass and Organ Weights Characteristic of Broiler Finisher Fed Varying Levels of Tigernut (Cyperus esculentus L) Meal as Dietary Supplement. British Journal of Poultry Sciences, 2012. 1(2): $11-17$

Alabi, B. S., Ayeni, A. O., Agboola, A. A. and Majek, B. A. 2001. Giant Sensitive Plant Interference in Cassava. Weed Science. 49:171-176

Amao, S. R., Oyewumi, S. O., Olatunde, A. K., Oguntunde, M. M. 2015. Carcass Indices and Organoleptic Properties of Organically Raised Broiler Chickens in Derived Savanna Zone of Nigeria. Journal of Natural Sciences Research. 5(20): 5-10

Andrea Luciana dos Santos, Nilva Kazue Sakomura, Ednardo Rodrigues Freitas, Cristina Maria Lima Sá Fortes, Elma Neide Vasconcelos Martins Carrilho and João Batista Kochenborger Fernanades. 2005. Growth Performance, Carcass Yield and Meat Quality of Three Broiler Chicken Strains. Revista Brasileira de Zootecnia. 34(5): 
1589-1598

Anon. 2001. Mimosa diplotricha. ILDIS World Database of Legumes. http://www.Ildis.org/LegumeWeb/ 6.00/taxa/73.shtml.

Ayo-Ajasa, O. Y., Abiona, J. A., Fafiolu, A. O., Egbeyale, L. T., Njoku, C. P., Omotayo, I. G., Odeyemi, A.Y. and Abel, F. A. S. 2016. Performance characteristics of broilers fed graded levels of Moringa oleifera leaf meal. Malaysian Journal of Animal Science. 19(1): 23-31

Barylko-Pikielna, N. 1975. Outline of Food Sensory Analysis. Ed. PWN, Warszawa

Behnke, K. C. and Beyer, S. R. 1994. Effect of Feed Processing on Broiler Performance. Kansas State University. Manhattan, Kansas

Chinelo, E. A., Elizabeth, M. U. 2016. Phytochemical and Proximate Investigations of leaf, root and stem of Mimosa Invisa mart. and M. Pudica L. Journal of Pharma Science. 1(1): 25-29

Cross, D. E. 2004. Phytochemical and enzyme supplementation of broiler chicken diets and the effects on intestinal microflora, nutrient utilisation and performance. $P h D$, Scottish Agricultural College and The University of Glasgow

Dariusz Kokoszyński, Zenon Bernacki, Henryka Korytkowska, Krzysztof Krajewski and Lidia Skrobiszewska. 2013. Carcass composition and physiochemical and sensory properties of meat from broiler chickens of different origin. Journal of Central European Agriculture. 14 (2): 303315
Darryl, D., Steve, B., Aziz, S. and Andreas, K. 2007. Global feed issues affecting the Asian poultry industry: Poultry in the $21^{\text {st }}$ Century. Alltech Biotechnology, Asia Pacific. 1(10): 1-4

Diarra, S. S., Sandakabatu, D., Perera, D ., T a b u a c i r i, P. a nd Mohammed, U. 2014. Growth P e r form a n c e, C a r c a s s Measurement and Organ Weight of Broiler Chickens fed Cassava Copra Meal-Based or Commercial Finisher Diets in Samoa. Asian Journal of Poultry Science. 8(1):16-22

Duncan, D. B. 1955. Multiple Range and Multiple F-test. Biometrics. 11:1-42

Esonu, B. D., Iheukwumere, F. C., lwuji, T. C., Akanu, N., Nwugo, O. H. 2003. Evaluation of Microdesmis puberula leaf meal as Feed Ingredient in Broiler Starter Diets. Nigerian Journal of Animal Production. 30: 3-8

Fajohunbo, G. O. 2010. Effect of Ocimum Gratissimum leaf meal on the haematological parameters of broilers. B. Agric, University of Agriculture, Abeokuta, Ogun State

Fernandes Jovanir Inês Müller, Cristiano Bortoluzzi, Gustavo Eugênio Triques, Américo Fróes, Garcez Neto and Daniela Cristina Peiter. 2013. Effect of Strain, Sex and Age on Carcass Parameters of Broilers. Acta Scientiarum. 35(1): 99-105

González-Alvarado, J. M., JiménezMoreno, R., Mateos, G. G. 2007. Effects of Type of Cereal, Heat Processing of the cereal and Inclusion of Fibre in the Diet on Productive Performance and Digestive Traits of Broilers. 
Poultry Science. 86(8): 1705-1715

Graham, H. N. 1992. Green Tea Composition, Consumption and Polyphenol Chemistry. Prev. Med. 21:334-350

Holm, L. G., Plucknett, D. L., Pancho, J. V. and Herberger, J. P. 1977. The World's Worst Weeds: Distribution and Biology. Honolulu. The University Press of Hawaii. 328-331

Johnson, C. and McNab, J. M. 1983. Grain Meal as an Ingredient in Diets of Broiler Chicks. British Poultry Science. 24: 361-369

Kow Benyi, Thendo Stanley Tshilate, Avhafunani Justice Netshipale, Kgabo Tryphina Mahlako 2015. Effects on the Growth Performance and Carcass Characteristics of Broiler Chickens. Tropical Animal Health and Production. 47(7). 1225-1231

Martinez, Y., Carrion, Y., Rodriguez, R., Valdivie, M., Olmo, C., Betancur, C., Liu, G., Al-Dhabi, N. A. and Duraipandiyan, V. 2015. Growth Performance, Organ Weights and Some Blood Parameters of Replacement Laying Pullets fed with Increasing Levels of Wheat Bran. Brazilian Journal of Poultry Science. 17(3): 347-354

Afolayan, M. O. and Afolayan, M. 2008. Nigeria Oriented Poultry Feed Formulation Sof t ware Requirements. Journal of Applied Sciences Research. 4(11): 15961602

Meremikwu, V. N., Ibekwe, H. A. and Essien, A. 2013. Improving Broiler Performance in the Tropics using Quantitative Nutrition. World's Poultry Science Journal. 69: 633638
Nworgu, F.C. 2015. Centrosema (Centrosema pubescens) leaf meal as a Protein Supplement for Broiler Chicks Production. Journal of Experimental Biology and Agricultural Sciences. 3(5): 440447

Nworgu, F. C. and Egbunike, G. N. 2013. Nutritional Potential of Centrosema pubescens Mimosa invisa and Pueraria phaseoloides Leaf Meals on Growth Performance Responses of Broiler Chickens. American Journal of Experimental Agriculture. 3(3): 506-519

Odunsi, A. A. 2003. Assessment of Lablab (Lablab purpureus) leaf meal as a Feed Ingredient and Yolk Colouring Agent in the Diet of Layers. International Journal of Poultry Science. 2: 71-74

Okah, U. and Onwujiariri, E. B. 2012. Performance of Finisher Broiler Chickens fed Maggot meal as a Replacement for Fish meal. Journal of Agricultural Technology. 8: 471-477

Olawumi, S. O. and Fagbuaro, S. 2011. Productive Performance of Three Commercial Broiler Genotypes Reared in the Derived Savannah Zone of Nigeria. International Journal of Agricultural Research. 6(11): 798-804

Olowu, O. P. A., Asaniyan, E. K., Agbede, J. O. 2013. Performance, Organ Growth and Economics of Finisher Broiler fed Neem (Azadirachta indica) leaf meal as Replacement for Maize. Nigerian Journal of Animal Production. 40(2): 45-51

Svihus, B. 2011. The Gizzard: Function, Influence of Diet Structure and Effects on Nutrient Availability. 
World's Poultry Science Journal. 67: 207-224

Taha, A. E., Abd El-Ghany, F. A. and Sharaf, M. M. 2010. Production Traits of Broiler Chicken Strains fed Ad Libitum and Raised on Deep Litter System in the Humid Tropics. Animal Research International.9(1): 1529-1536

Tuleun, C. D. and Igba, F. 2007. Growth and Caracass Characteristics of Broiler Chickens fed Soaked and Cooked Velvet Bean (Mucuna utilis) meal. Proceedings of the $32^{\text {nd }}$ Annual Conference of Nigerian Society for Animal Production, Calabar, Nigeria. 240-243
Ravindran, V.1992. Main ingredients used in poultry feed formulations. Poultry feed availability and nutrition in developing countries. 72-75

Received: $13^{\text {th }}$ November, 2017

Accepted: $20^{\text {th }}$ February, 2018 